\section{ORCHIDS IN GOVERNMENT BOTANICAL GARDEN UDHAGAMANDALAM, THE NILGIRIS, TAMIL NADU}

\author{
C. Ram Prasad ${ }^{1}$, V. Ram Sundar ${ }^{1}$ and S. Rajan ${ }^{2}$ \\ ${ }^{1}$ Government Botanical Garden, Udhagamandalam, Tamil Nadu \\ 643001, India. \\ ${ }^{2}$ Survey of Medicinal Plants and Collection Unit $(H)$, Government \\ Arts College Campus, Udhagamandalam, Tamil Nadu 643002,
}

India.

The Botanical Garden, was established in 1847 by Marquies Tweedale by collecting subscriptions from the European residents in the Nilgiris. The first curator Mr. W.G. Mclvor from Kew developed the garden and gave a definite shape to it. It covers an area of about 51 acres at an elevation 2200-2400m. The average annual rainfall is $1400 \mathrm{~mm}$. With occasional frosty nights from December to February and the temperature fluctuates between $28^{\circ} \mathrm{C}$ and $0^{\circ} \mathrm{C}$. The lawns are beautifully laid out and planted with indigenous and exotic ornamental trees, shrubs and herbs. There is a fine terrace laid out with flower beds in Italian style, three conservatories, and a range of glass houses for propagating and nursing plants of special interests in this garden. (Nathan, 1941; Price, 1908).

The garden is divided into six different sections, viz.

1. Lower garden

2. New garden

3. Italian garden

4. Conservatory

5. Fountain terrace

6. Nurseries

\section{Objectives of the Garden}

1. To promote horticultural activities in this district and also in the state of Tamil Nadu.

2. To serve as a reference centre for researchers and students of horticulture, botany and allied subjects.

3. To introduce exotic ornamental plants of economic importance.

4. To collect and maintain a record of information on the flora of Nilgiris, including exotic collections.

5. To take suitable conservatory steps to preserve the Nilgiri Biosphere. The rare, endangered and economic plants of the region will be propagated by in vitro methods.

Received on 25 April 2000

Accepted on 28 November 2000
Among the wild flowers of Nilgiri Biosphere, orchids are very important and much sought after in international floricultural trade. They are beautiful multicoloured forms representing one of the largest families in the flowering plants group. The Western Ghats, especially the Nilgiris constitute one of the richest natural orchid treasure houses comprising 113 species reported by Sharma et al. (1977), 121 species reported by Joseph (1987) and 128 species reported by Henry et al. (1989).

The conservation of natural resources in situ or by ex situ methods in many conservatories has increased rapidly today. In recent times, owing to changes in human life style and due to anthropogenic pressure by the locals, many plants face threats in the wild and need to be conserved.

A collection of 49 species of orchids from within Nilgiri forest area and outside for ex situ conservation. They are either terrestrial or epiphytic. The terrestrial orchids are cultivated using pots with pieces of brick, charcoal and leaf mould in the ratio 2:2:1. The epiphytic orchids are grown in pots or beds equal parts of brick and charcoal pieces without leaf mould. Further, epiphytic orchids are suspended on dead wood pieces tied with moss and are periodically watered. Manure is seldom applied. We have adopted this recommended procedure as practised by the National Orchidarium, Yercaud (Ansari \& Dwarakan, 1995). The plant growth and phenology and related observations are under progress.

The nomenclature has been updated by Sarkar (1995). The orchids listed in Table 1 have been selected for ex situ conservation; and the asterix $(*)$ indicates those that are endemic to the Western Ghats. The list of orchids mentioned in Table 2 is taken for conservation for its economic value of cut flowers.

\section{References}

Ansari, A.A. and P. Dwarakan (1995). Studies on the orchids of National Orchidarium and Experimental Garden, Yercaud, Tamil Nadu. Journal of Economic and Taxonomic Botany Additional Series 11: 129-142.

Joseph, J. (1987). Orchids of Nilgiris. Botanical Survey of India, Calcutta.

Henry, A.N., V. Chithra and N.P. Balakrishnan (1989). Flora of Tamil Nadu - Series I Analysis Vol. 3. Botanical Survey of India, Coimbatore.

Nathan, P.A. (1941). Catalogue of ornamental plants, seeds, etc. for sale at the Governmental Botanical Garden, Nilgiris, Ootacamund. The Superindent Government Press, Madras.

Price, F. (1908). Ootacamund - A history. Superintendent Government Press, Madras.

Sarkar, P.K. (1995). An up-to-date census of Indian orchids. Journal of Economic and Taxonomic Botany Additional Series 11: 1-32.

Sharma, B.D. (1997). Studies on the Flora of Nilgiris. Tamil Nadu. Biological Memoirs 2(1\&2): 1-186.

Smith, G.H. (1958). Conservation of Natural Resources. John Wiley \& Sons, Inc., New York. 
Table 1. Orchids in Botanic Gardens for ex situ conservation.

1. Aerides crispum Lindley

2. Arundina gramnifolia (D.Don) Hochr. (= A. bambusifolia Lindley)

3. Bulbophyllum fusco-purpureum Wight *

4. Bulbophyllum neilgherrense Wight

5. Calanthe masuca (D. Don) Lindley

6. Coelogyne mossiae Rolfe *

7. Coelogyne nervosa A. Rich. *

8. Coelogyne odoratissima Lindley

9. Cymbidium aloifolium (L.) Sw.

10. Dendrobium aphyllum (Roxb.) C. Fischer (= Limodorum aphyllum Roxb.; = Dendrobium pierardi Roxb. ex Hook. f.)

11. Dendrobium macrostachyum Lindley

12. Dendrobium moschatum (Buch.-Ham.) Sw. (= Epidendrum moschatum Buch.-Ham.)

13. Eria nana A. Rich. *

14. Eulophia nuda Lindley

15. Habenaria heyneana Lindley*

16. Oberonia brunoniana Wight*

17. Oberonia wightiana Lindley

18. Pepilionanthe subulata (Koening) Garay (=Aerides cylindricum Lindely)

19. Rhynchostylis retusa (L.) Blume (= Epidendrum retusum $\mathrm{L}$.)

20. Vanda tessellata (Roxb.) Hook. ex G. Don (= Vanda roxburghii R. Br.)

21. Vanda testacea (Lindley) Reichb. f.
Table 2. Orchids under cultivation in the Garden for commercial purposes.

1. Aerides multiflora Roxb.

2. Aerides odorata Lour.

3. Arundina chinensis Blume

4. Coelogyne cristata Lindley

5. Coelogyne holochila Hunt \& Summerh. (= C. elata Hook. non Lindley)

6. Coelogyne nitid (Wallich) Lindley (= Cymbidium nitidum Wallich; Coelogyne ochreacea Lindley)

7. Cymbidium eburneum Lindley

8. Cymbidium hookerianum Reichb. (= C. grandiflorum Griffith)

9. Cymbidium lancifolium Hook.

10. Cymbidium lowianum Reichb. f. (= C. giganteum Wallich var. lowiana Reichb.)

11. Cymbidium pendulum (Roxb.) Sw.

12. Dendrobium bicameratum Lindley ( $=D$. bulboflorum Falc. Ex Hook. f.)

13. Dendrobium chrysotoxum Lindley

14. Dendrobium fimbriatum Hook (= D. fimbriatum Hook. var. oculatum Hook.)

15. Denrobium nobile Lindley

16. Dendrobium primulinum Lindely

17. Phaius flavus (Blume) Lindley (= Limodorum Blume)

18. Phaius maculatus Lindley

19. Phaius mishmensis Reichb.

20. Phaius tankervilleae (L'Herit) Blume (= Limodorum lankervilleae Banke ex L'Herit; Phaius wallichi Lindley)

21. Phalaenopsis mannii Reichb. f.

22. Pleione hookeriana (Lindley) J. Moore (= Coelogyne hookeriana Lindley)

23. Pleione raecox (Smith) D. Don (= Epidendrum praecox Smith; Coelogyne praecox (Smith) Lindley; C. lagenaria Lindley)

24. Renanthera imscheotrana Rolfe

25. Thunia alba (Lindley) Reichb. f. *

26. Vanda coerulea Griffith

27. Vanda cristata Lindley

28. Vanda parishii Veitch. 